\title{
Periglacial disruption and subsequent glacitectonic deformation of bedrock: an example from Anglesey, North Wales, UK
}

\author{
Emrys Phillips $^{1 *}$, Jonathan R. Lee ${ }^{2}$, James B. Riding ${ }^{2}$, Rhian Kendall ${ }^{3}$, Leanne Hughes ${ }^{2}$ \\ 1. British Geological Survey, Murchison House, West Mains Road, Edinburgh EH9 \\ 3LA, UK \\ 2. British Geological Survey, Kingsley Dunham Centre, Nicker Hill, Keyworth, \\ Nottingham NG12 5GG, UK \\ 3. British Geological Survey, Columbus House, Greenmeadow Springs, Tongwynlais, \\ Cardiff, CF15 7NE, UK \\ *corresponding author \\ telephone: +44 (0)131-667-1000, fax: +44 (0)131-668-2683, e-mail - erp@bgs.ac.uk
}

\begin{abstract}
The deformed metasedimentary bedrock and overlying diamictons in western Anglesey, NW Wales, record evidence of glacier-permafrost interactions during the Late Devensian (Weichselian). The locally highly brecciated New Harbour Group bedrock is directly overlain by a bedrock-rich diamicton which preserves evidence of having undergone both periglacial (brecciation, hydrofracturing) and glacitectonic deformation (thrusting, folding), and is therefore interpreted as periglacial head deposit. The diamicton locally posses a welldeveloped clast macrofabric which preserves the orientation of the pre-existing tectonic structures within underlying metasedimentary rocks. Both the diamicton and New Harbour Group were variably reworked during the deposition of the later Irish Sea diamicton, resulting in the detachment of bedrock rafts and formation of a pervasively deformed glacitectonite. These structural and stratigraphic relationships are used to demonstrate that a potentially extensive layer of permafrost developed across the island before it was overridden by the Irish Sea Ice Stream. These findings have important implications for the glacial history of Anglesey, indicating that the island remained relatively ice-free prior to its inundation by ice flowing southwards down the Irish Sea Basin. Palynological data obtained from the diamictons across Anglesey clearly demonstrates that they have an Irish Sea provenance. Importantly no Lower Palaeozoic palynomorphs were identified, indicating that it is unlikely that Anglesey was overridden by ice emanating from the Snowdon ice cap developed on the adjacent Welsh mainland. Permafrost was once again re-established across Anglesey after the Irish Sea Ice Stream had retreated, resulting in the formation of involutions which deform both the lower bedrock-rich and overlying Irish Sea diamictons.
\end{abstract}

Keywords: periglacial deformation, glacially tectonised bedrock, Anglesey, Irish Sea Ice 


\section{Introduction}

Research on the interactions between glaciers and permafrost has, until recently, been relatively limited (e.g. Haeberli, 2005; Harris and Murton, 2005; Waller, 2001; Waller et al., 2011; 2012) with the two phenomena commonly being viewed as mutually exclusive. This exclusivity has been primarily founded upon the insulating effects caused by a thick layer of ice overlying the bed and thereby protecting it from the prevailing climate and/or frictional heating resulting from the movement of the glacier over its bed leading to the rapid degradation of any permafrost present. Furthermore, where glaciers have been observed overlying permafrost, the resulting cold-based ice is usually thought to preclude processes such as basal sliding and subglacial sediment deformation, with such glaciers being regarded as 'frozen to their beds', slow moving and geomorphologically inactive. Recently, however, there has been an increasing recognition that glaciers and permafrost can and do interact (see Waller et al., 2012 for a review). These studies have shown that whilst the extent of permafrost beneath large ice masses may be limited, glacier-permafrost interactions are likely to be more common during periods of ice advance, when pre-existing permafrost is overridden and persists for significant periods due to its thermal inertia (Mathews and Mackay, 1960; Cutler et al., 2000; Waller et al., 2012). Waller (2001) demonstrated that, in both modern and ancient cold environments, subglacial processes (e.g. bed deformation, landform development) can remain active at subfreezing temperatures, thereby influencing glacier dynamics (also see Echelmeyer and Zhongxiang, 1987; Cuffey et al., 1999; Fitzsimons et al., 1999; Bennett et al., 2003). Astakhov et al. (1996) and Murton et al. (2004) working in the formerly glaciated parts of Siberia and the Western Canadian Arctic have shown that cold-based glaciers can actively couple with and deform substantial thicknesses of permafrost. Although evidence for glacier-permafrost interactions can be clearly demonstrated in regions where the permafrost has remained intact, discriminating between the subglacial deformation of unfrozen versus permafrozen materials in the geological record, where the permafrost has long since thawed, has proved more problematical (Waller et al., 2011, 2012).

This paper presents evidence from the coastal cliff sections of western Anglesey in northwest Wales recording the development of a permafrost layer prior to the island having been overridden by the Devensian (Weichselian) Irish Sea Ice Stream. The metasedimentary bedrock and overlying bedrock-rich diamicton in this area locally preserve clear evidence of having undergone both periglacial and glacitectonic deformation. The interrelationships between these deformation structures has allowed a relative chronology of events to be established, which indicates that the Irish Sea Ice overrode and interacted with a pre-existing permafrost layer. These findings have important implications for the glacial history of Anglesey, indicating that it may have remained relatively ice-free until its inundation by ice flowing southwards down the Irish Sea Basin.

\section{Location of study area and methodology}

This study focused on the low costal cliff sections (ranging in height from 1 to $10 \mathrm{~m}$ ) between Porth Penrhyn-mawr (National Grid Reference SH 287 852) and Porth Tywyn-mawr (SH 286 
837) in western Anglesey, northwest Wales (Figs. 1 and 2). The glacial sediments and bedrock exposed in these cliff sections were mapped and described based on their sedimentological, lithological and structural characteristics. A sequence of photographs were taken of key parts of the cliffs enabling the detailed analysis of the small- and meso-scale structures developed within the diamictons and underlying schistose metasedimentary bedrock. The orientations of primary bedding and deformation structures (folds, cleavages, joints) were measured using a compass clinometer. The sense of asymmetry of various fold phases and movement on the faults, and inter-relationships between the various generations of structures were established. Successive generations of folds (F1, F2.....Fn), fabrics (S1, S2.....Sn) and lineations (L1, L2 .....Ln) are distinguished by the nomenclature normally used in structural geological studies (S1 earliest fabric to Sn latest) (Phillips et al., 2011). Bedrock structures preserved within the bedrock-rich diamicton are distinguished by the prefix $\mathrm{dm}$, for example S1dm. Additionally, 11 diamicton samples from across Anglesey were collected for the palynological analysis in order to establish the provenance of these deposits (Table 1). The samples were prepared using the sodium hexametaphosphate separation method of Riding and Kyffin-Hughes (2004, 2006) and the results are summarised in Table 1.

\section{The glacial geology of Anglesey}

During the Late Devensian (Weichselian), Anglesey (Fig. 1a) was located close to the eastern margin of the Irish Sea Ice Stream (Thomas and Chiverrell, 2007; Phillips et al., 2010). This corridor of relatively faster moving ice, sourced in central and southwest Scotland, flowed southwest down the Irish Sea Basin (Merritt and Auton, 2000; Evans and Ó Cofaigh, 2003; Roberts et al., 2007) where it met, coalesced with and ultimately decoupled from ice emanating from the Welsh Ice Sheet centred on Snowdonia (McCarroll, 2005; Thomas and Chiverrell, 2007). The Irish Sea Ice Stream is one of a number of ice streams that helped regulate the size and shape of the British and Irish Ice Sheet, and at its maximum extent, reached the Isles of Scilly (Scourse, 1991a and b; Hiemstra et al., 2006; Thomas and Chiverrell, 2007; Phillips et al., 2010; Clark et al., 2012). Although Eyles and McCabe (1989) argued that during the Late Devensian the floor of the Irish Sea was isostatically depressed, interpreting most of the glacigenic sequences below $100 \mathrm{~m}$ OD as glaciomarine in origin, most workers have agreed that the advance and retreat of Irish Sea Ice was principally terrestrial (for example see Merritt and Auton, 2000; McCarroll, 2001; Hambrey et al., 2001; Ó Cofaigh and Evans, 2001; Scourse and Furze, 2001; Evans and Ó Cofaigh, 2003; Thomas et al., 2004; McCarroll, 2005; Thomas and Chiverrell, 2007; Roberts et al., 2007).

The glacial geomorphology and sedimentary succession preserved on Anglesey has largely been interpreted as providing a record of the processes that occurred beneath the Irish Sea Ice Stream. Thomas and Chiverrell (2007) and Phillips et al. (2010) divided this sequence into three sediment-landform assemblage zones (Fig. 1b):

- Zone 1 - an extensive subglacial depositional assemblage covering much of northern and western Anglesey, and dominated by an extensive drumlin field (Greenly, 1919). 
The drumlins vary from being mainly composed of diamicton, through to bedrock dominated features encased in a relatively thin carapace of this diamicton;

- Zone 2 - a subglacial erosional assemblage of northeast-southwest-trending icemoulded bedrock ridges forming an elongate tract across the central part of the island;

- Zone 3 - an undifferentiated subglacial erosional and depositional assemblage of elongate bedrock ridges, solitary drumlinoid landforms, bedrock channels and proglacial outwash (Helm and Roberts, 1984) and subglacial (esker) deposits, that cover the remainder of the island.

Geomorphological mapping of part of the offshore area to the north of Anglesey (Van Landeghem et al., 2009) has shown that a comparable suite of glacigenic landforms occur beneath this part of the Irish Sea. Phillips et al. (2010) demonstrated that changes in the morphology, orientation and distribution of the subglacial landforms on Anglesey closely matches the underlying bedrock, concluding that bedrock geology potentially played an important role in controlling the relative velocity of the overriding Irish Sea Ice.

\section{Bedrock and Quaternary geology of the study area}

The bedrock geology of the study area is dominated by polydeformed metasedimentary (greenschist to sub-greenschist facies) rocks of the New Harbour Group (Fig. 1c) (Greenly, 1919; Maltman, 1977; Phillips 1989; 1991a and b). This thick (estimated thickness c. 2000$3000 \mathrm{~m}$ ) sequence of highly schistose metamudstones and volcaniclastic metasandstones forms part of the Monian Supergroup of Cambrian age (Shackleton, 1975; Phillips, 1991a; Collins and Buchan, 2004; Howells, 2007). Elsewhere on Anglesey, these highly deformed rocks are unconformably overlain by an Arenig (Lower Ordovician) overstep (transgressive) sequence of marine sandstones, conglomerates and mudstones (Bates, 1972, 1974; Beckly, 1987). In the study area, the pale to dark green, chlorite-quartz-schists which dominate the New Harbour Group contain lenses or horizons of highly schistose, purple phyllite (the 'jaspery phyllites' of Greenly, 1919) and a number of fault-bounded, lenses of metabasaltic volcanic rocks (Fig. 1c). These metabasaltic rocks represent the source of the large, metrescale erratic blocks present in the overlying sandy diamicton (Fig. 3a). Primary bedding within the New Harbour Group has largely been overprinted by a pervasive, bedding-parallel tectonic foliation (S1), which is itself deformed by several phases of asymmetrical, SEverging folds (F2 to F3) and associated axial planar cleavages (S2 to S3) (Greenly 1919; Maltman, 1977; Phillips, 1998, 1991b). Representative orientation data collected for these bedrock deformation structures (S1, F2 folds and joints) are shown on Fig. 4.

The study area occurs within sediment-landform assemblage zone 1 (Fig. 1b). Its geomorphology comprises a series of elongate, northeast-southwest-trending drumlins separated by low-lying areas of bedrock mantled by a thin layer of diamicton and/or colluvium (Fig. 1c). On the low-lying headland between Porth Penrhyn-mawr (SH 287852 ) and Porth Tywyn-mawr (SH 286 837) a relatively flat to gently undulating layer of diamicton thickens towards the south (maximum thickness 8-10 $\mathrm{m}$ ). The relative positions of the coastal cliff sections through the superficial deposits and underlying bedrock, referred to in the text, 
are shown on both Figs. 1 and 2. Where exposed (e.g. Porth Dryw (SH 282 840); Figs. 1 and 2) the superficial sequence comprises a lower, massive grey diamicton dominated by very locally derived bedrock fragments (see below), overlain by a weakly to moderately stratified brown, sandy Irish Sea diamicton (Fig. 3a). This bipartite sequence of diamictons is exposed at several sites across Anglesey including Cemlyn Bay, Penrhos Beach, Penrhos Headland, the coastal section at Newlands near valley, Porth Nobla, Porth Cwyfan and near Beaumaris (Fig. 1b). Both diamictons are over consolidated, consistent with them having been overridden by ice, and range in texture from clast- to matrix- supported. The boundary between the two diamictons is sharp and locally marked, or immediately overlain, by a pronounced boulder-rich pavement or layer. The upper, sandy diamicton contains a high proportion of far-travelled detritus including Carboniferous sandstone and limestone, Devonian sedimentary rocks and less common granitic rocks, as well as large (1.5-2.5 m diameter) erratic boulders of metabasalt (Fig. 3a) and is therefore interpreted as having been deposited by ice flowing down the Irish Sea (i.e. the Irish Sea diamicton). Both the bedrockrich and sandy diamictons preserve evidence of periglacial activity (e.g. at (SH 28438395 ) on the northern-side of Porth Penrhyn-mawr) including convolute-style folding (involutions) (Fig. 3b, also see Fig. 2) and locally well-developed vertical clast macrofabrics (Fig. 3c). Similar periglacial involutions and fabrics are observed elsewhere on Anglesey, for example at Porth Cwyfan (SH 337 684) on the southwest coast of the island, to the east of Rhosneigr (Fig. 1b) (also see Greenly, 1919).

\section{Clast macrofabrics and deformation of the bedrock-rich diamicton}

The New Harbour Group in the study area is directly overlain by a 1 to $3 \mathrm{~m}$ thick clast- to matrix-supported, bedrock-rich diamicton (Fig. 5). The boundary between the two ranges from a highly irregular to sharp, planar contact defined by the laterally extensive, gently NWdipping S1 surfaces within the schists, to highly irregular; the latter corresponding to areas in which the pre-existing S1 bedrock fabric is more steeply inclined on the short, overturned limbs of mesoscale (F2) folds. Although the contact is clearly erosive, truncating pre-existing bedrock structures (S1, F2...etc), no obvious striae have been recorded on exposed surfaces. The diamicton is mainly composed (95 to $100 \%$ of the clast assemblage) of angular, blocky to tabular fragments (up to $50 \mathrm{~cm}$ in length, typically between 5 and $20 \mathrm{~cm}$ long) of very locally derived New Harbour Group schist (Figs. 5 to 8). The morphology of the bedrock clasts is strongly controlled by the bedrock S1 fabric (Figs. 5b and c). A fine-grained, chloritic matrix to the diamicton is largely derived from highly degraded and/or fragmented bedrock. Adjacent to the overlying sandy diamicton, however, this chloritic matrix becomes more sandy (quartzose) in nature, indicative of at least some intermixing between these two deposits.

Three distinct 'facies' have been recognised within the bedrock-rich diamicton: (i) a matrix-poor, clast-supported diamicton in which the closely packed bedrock fragments defining a well-developed clast macrofabric (here referred to as S1dm) (Figs. 4d, 5 and 6); (ii) a typically massive (Fig. 5c) to locally normally graded (Fig. 7a) clast- to matrixsupported facies which lacks any obvious clast macrofabric and comprising randomly 
orientated blocks; and (iii) a stratified facies in which the variably developed layering, defined by the variation in grain size, clast macrofabric and matrix content, is deformed by locally developed open folds and/or subhorizontal to gently northerly dipping 'shears' (Figs. $7 \mathrm{~b}$ and 8). Facies (iii) is most common and characterises the bedrock-rich diamicton exposed in western Anglesey; for example, in the coastal sea cliffs on western-side of the headland west of Cemlyn Bay (see Fig. 1b).

In the study area, facies (i) occurs immediately above and grades into the underlying bedrock. Orientation data obtained for the tectonic fabric present within the aligned rock fragments (here referred to as S1dm) are comparable to that of the S1 fabric recorded from the in situ New Harbour Group exposed in the adjacent foreshore (compare Figs. 4a and d, also see Fig. 5). Data obtained for the bedrock structures and orientation of the tectonic fabric present within the schistose rock fragments within the diamicton (S1dm) are shown graphically in Figs 5d to g (also see Fig. 4d). S1, within the bedrock, plots in two tight clusters on Fig. 5d, reflecting the reorientation of this fabric by the F2 folds. In contrast, data obtained for S1dm within the massive diamicton shows a more random distribution, consistent with the rotation of the clasts during deposition. As expected, data obtained for S1dm in the diamicton with the pronounced clast macrofabric plots in a tight cluster (Fig. 5f), immediately adjacent to the field defined by S1 in the underlying bedrock (compare Figs. 5d and f). S1dm data for the entire section are shown on Fig. 4d and shows that there is a close correlation between the orientation of the clasts within the diamicton and S1 within the underlying bedrock. These data clearly indicate that the S1dm clast macrofabric is coplanar to the pervasive S1 foliation within the New Harbour Group, demonstrating that this clast macrofabric was ‘inherited’ from the underlying bedrock (Phillips and Auton, 2007).

Similarly, the S3 foliation and F3 kink-style folds preserved within the schistose rock fragments in the diamicton (Fig. 6) also show little, or no, evidence of having been reorientated during the formation of this deposit. The size of the rock fragments in facies (i) diamicton decreases upwards (Fig. 6a) with the New Harbour Group schist having parted along S1 and, to a lesser extent, the weaker S3 cleavage (Fig. 6b). The resulting expansion of the bedrock occurred both horizontally, associated with the opening of the more pervasively developed S1 fabric, and vertically due to the opening along the heterogeneous S3. This deformation was accompanied by the introduction of the chloritic to locally sandy matrix into the opening fractures. The preservation of the primary orientation of the S1 fabric by the S1dm macrofabric clearly indicates that bedrock fragmentation was achieved without any significant rotational deformation during the formation of the diamicton (Phillips and Auton, 2007); i.e. no obvious simple shear component typically equated with subglacial deformation. To the south of Porth Delysg (e.g. at (SH 2808 8410); see Figs. 1 and 2), the S1dm clast macrofabric is clearly truncated at the base of the overlying sandy Irish Sea diamicton (Fig. 5a). There is no obvious reorientation or deformation (e.g. folding) of this macrofabric adjacent to this irregular, erosive contact (see Figs. 5a and b).

Elsewhere in the study area, the facies (i) diamicton is directly overlain, or passes laterally into either facies (ii) or (iii). The massive, jumbled appearance of facies (ii) (Figs. 5c and 7a) is consistent with any earlier formed clast macrofabric (S1dm) having been lost or 
overprinted. Contacts between this massive diamicton and facies (i) are sharp to gradational, with the loss or overprinting of the S1dm macrofabric occurring over a space of 10 to $20 \mathrm{~cm}$. Clast orientation data obtained from the layered/stratified facies (iii), however, indicates that the S1dm macrofabric is variably preserved within this diamicton (Fig. 8). The increased scatter of the data, for example within layer 3 (see Fig. 8c), is equated with the varying degrees of rotation during the progressive overprinting of the S1dm macrofabric inherited from the New Harbour Group bedrock. The boundaries between the layers are marked by thin zones of finer grained rock fragments that exhibit a preferred shape alignment parallel to the stratification. This layer-parallel clast macrofabric (S2dm) occurs throughout the diamicton (see Fig. 8b), replacing/overprinting the more steeply inclined S1dm fabric.

\section{Evidence for glacitectonism of the New Harbour Group and bedrock-rich diamicton}

On the southern side of Porth Delysg (Figs. 1 and 2), both the superficial deposits and New Harbour Group begin to show more obvious signs of glacitectonism, including rafting of bedrock, hydrofracturing, brittle-ductile shearing and thrusting (Figs. 2, 9, 10 and 11, respectively).

At (SH 2813 8421) a 2.5 to $3 \mathrm{~m}$ long, lenticular raft of New Harbour Group is isolated within the bedrock-rich diamicton (Fig. 9). This asymmetrical (apparent sense of shear/displacement towards the south) raft is bound by thin, 5 to $10 \mathrm{~cm}$ thick brittle shear zones (detachments) composed of a much finer grained diamicton. An asymmetrical foliation developed within these shear zones records a sense of displacement towards the south (in this plane of section), consistent with the predominantly south-westerly directed flow of ice across Anglesey. Preserved within the raft is a mesoscale, moderately-inclined, asymmetrical, SE-verging F2 fold deforming S1 fabric (Fig. 9b). This fold and associated minor parasitic F2 structures plunge gently towards the northeast, comparable to similar structures present within the bedrock exposed in the adjacent foreshore (Fig. 4c). This evidence indicates that the raft has undergone very little, or no, rotation during the rafting process. Furthermore, the New Harbour Group within the raft is highly fractured (Fig. 9a), largely due to the opening of pre-existing joints (see Fig. 4b) and S1 fabric. There is no evidence of these fractures having propagated into the host diamicton, suggesting that brittle fracturing of the bedrock occurred prior to its incorporation within the diamicton. Although fractured, this bedrock raft remained intact during its detachment and subsequent transport. Similar rafts of New Harbour Group bedrock have also been observed further north along the western coast of Anglesey at (SH 2924786643 ) on the headland immediately to the north of Porth Trefadog.

The New Harbour Group immediately to the north of the raft site in Porth Delysg is cut by a network of 1 to $4 \mathrm{~cm}$ wide hydrofractures filled by highly fragmented, fine-grained (up to $2 \mathrm{~cm}$ ) fragments of chlorite-quartz-schist and vein quartz within a chloritic to locally sandy matrix (Figs. 10a and b); the latter being lithologically similar to the matrix of the overlying bedrock-rich diamicton. Similar sediment-filled hydrofractures cutting the bedrock were described by Harris (1991) from Wylfa Head. At Porth Delysg (Fig. 2), the diamicton 
overlying the hydrofractures bedrock possesses a variably developed planar to asymmetrical foliation defined by small (1 to $3 \mathrm{~cm}$ ) fragments of chlorite-quartz-schist (Fig. 10c). This brittle foliation can be subdivided into four main components: (i) a moderate to steeply northerly dipping planar to asymmetrical fabric (Si on Fig. 10c), the geometry of which yields a southerly-directed sense of shear; (ii) a sub-horizontal foliation (Sii on Fig. 10c); (iii) a poorly developed moderately northerly dipping fabric (Siii on Fig. 10c) which appears to truncate the first two fabric sets; and (iv) a moderate to shallowly southerly dipping fabric (Siv on Fig. 10c). The geometry and shear sense of these foliations are compatible with S, Y, $\mathrm{P}$ and $\mathrm{R}$ Riedel shears, respectively, developed in response to brittle deformation (Passchier and Trouw, 1996). Importantly these fabrics all record a southerly directed sense of shear, coincident with the ice movement direction across this part of western Anglesey.

At the northern end of the section, both the New Harbour Group and bedrock-rich diamicton are highly sheared and deformed by a complex set of low-angle brittle faults defining a 1 to $2 \mathrm{~m}$ wide brittle shear zone (Figs. 2 and 11). In the diamicton, shearing resulted in a marked decrease in its overall grain size (comminution), the variable overprinting of its coarse clastic texture and the imposition of a pervasive planar to sigmoidal brittle foliation within the resulting glacitectonite. The geometry of the brittle fabrics record a consistent south-westerly directed sense of shear (Fig. 11). At least two sets of brittle faults have been identified: (i) a set of gently to moderately northeast-dipping thrusts and reverse (compressional) faults; and (ii) a set of locally closely spaced, southwest-dipping normal (extensional) faults which offset the earlier developed thrusts (Fig. 11b). The sense of displacement on the faults has been established by the offset of both the glacitectonic fabric and lenses of pale coloured sandy diamicton, hematite stained diamicton and altered bedrock. Elsewhere along the section, both the bedrock and overlying diamicton are relatively unaltered. Consequently, the alteration (e.g. hematisation) encountered within the glacitectonite appears to have accompanied glacitectonism, possibly as a result of meltwater flowing along this brittle shear zone. The south-westerly shear sense recorded by both the fabrics and faults within the shear zone are once again consistent with the ice movement direction across this part of western Anglesey. However, these glacitectonic structures are truncated at the erosive base of the overlying Irish Sea diamicton (Fig. 11) indicating that deformation occurred prior to the deposition of this sandy diamicton.

\section{Formation and deformation of the bedrock-rich diamicton}

\subsection{Periglacial fragmentation of the New Harbour Group}

The bedrock-rich diamicton crops out across Anglesey, thereby indicating that the processes resulting in the brecciation/fragmentation of the underlying bedrock and its incorporation into this superficial deposit were widespread and not restricted to the present study area. For example, Harris (1991) described a similar bedrock-rich diamicton resting upon fractured/fragmented bedrock at Wylfa Head, interpreting the formation of this diamicton and disruption of the underlying bedrock as having occurred in response to glacitectonism beneath the warm-based Irish Sea Ice. Fragmented and involuted Ordovician mudstones and 
siltstones have also been observed at (SH 37992 86985) near Llanbabo, to the west of Llyn Alaw.

On the southern side of Porth Delysg (Fig. 2), the very locally derived, bedrock-rich diamicton is dominated by fragments of the underlying New Harbour Group. Lithological evidence suggests that the detritus in this bedrock-dominated diamicton has undergone relatively little lateral transport, with this superficial deposit having been formed essentially in situ. This conclusion is supported by the locally well-developed S1dm clast macrofabric in facies (i) which preserves the original orientation of the S1 fabric found within the subjacent bedrock (Figs. 4, 5 and 6). Any significant transport and/or disruption by the overriding Irish Sea ice would have resulted in the total loss (overprinting) of this inherited clast macrofabric. Elsewhere, however, the more jumbled/chaotic appearance of facies (iii) and glacitectonism of this diamicton and underlying bedrock does indicate that it was being reworked by the Irish Sea Ice (section 8).

In detail, facies (i) is locally almost entirely composed of closely packed, aligned fragments of schist (Fig. 6) and, therefore, simply represents fragmented New Harbour Group schist. Fragmentation of the bedrock led to an increase in its volume with expansion occurring both horizontally, as a result of fracturing along the pervasive S1 fabric (Fig. 6a), and vertically due to the opening of fractures along the heterogeneous S3 foliation (Fig. 6b). The preservation of the orientation of S1 by the S1dm clast macrofabric clearly indicates that fragmentation was achieved without any significant rotational deformation. This lack of clast rotation suggests that bedrock fragmentation did not occur in response to subglacial deformation (i.e. simple shear). The fact that the S1dm macrofabric is truncated by the base of the overlying sandy diamicton (Fig. 5) indicates that bedrock fragmentation occurred prior to the deposition of this sandy diamicton by the Irish Sea Ice. The overburden pressure imposed by the overlying ice would have also prohibited the vertical expansion of the bedrock during the fracturing process. Consequently, fragmentation of the bedrock on Anglesey is thought to have occurred as a result of periglacial activity prior to the island having been overridden by the Irish Sea Ice Stream.

Ballantyne and Harris (1994) describe similar associations of brecciated frostsusceptible bedrock overlain by diamicton (head) from elsewhere within the UK, in particular within the coastal cliff sections of Devon and Cornwall, and the Gower Peninsula of South Wales. In these areas the boundary between the intact bedrock and the overlying head is gradational, with the bedrock becoming increasingly shattered upwards and merging into the overlying head deposit. These very locally derived deposits are poorly sorted and composed of angular or very angular platy clasts of frost-weathered bedrock in a silty to sand matrix. A strong preferred downslope alignment of the clasts may be present, attributed to geliflucion and other slope processes (see Ballantyne and Harris 1994 and references therein). It is clear from the above that the bedrock-rich diamicton on Anglesey is texturally and sedimentologically very similar to unequivocal slope deposits described from elsewhere within the UK, supporting the interpretation that this deposit represents a partially reworked periglacial head deposit. 
Brecciation of bedrock in permafrost areas has been attributed to three principle mechanisms: (i) frost shattering within the active layer above the permafrost due to seasonal freezing and expansion of water trapped in pores and fractures, followed by thawing (Higginbottom and Fookes, 1970; Hall, 1999; Hall et al., 2002); (ii) brecciation due to thermal contraction and the growth of needles ice in the upper layer of permafrost (Büdel, 1982); and (iii) the growth of segregation ice in permafrost associated with perennial freezing leading to the formation of an ice-rich layer within the bedrock (ice content of 40 to $60 \%$ or more) just beneath the palaeo-permafrost table (French et al., 1986; Murton, 1996; Murton et al., 2006). Both processes lead to the formation of angular to subangular, pebble- to cobblesized clasts that are tabular in shape. Fragment size increases with depth, with a concomitant decrease in the relative displacement of the fragments. This variation in the morphology of the clasts is consistent with that observed within the facies (i) diamicton on Anglesey. Initial penetration of water into the New Harbour Group would have primarily been along the pervasively developed S1 fabric and, to a lesser extent, S3 fabric and joints. The growth of segregation ice along these pre-existing bedrock structures would have resulted in the progressive expansion and fragmentation of the bedrock, leading to the formation of the bedrock-rich diamicton, whilst preserving the orientation of these features within the inherited S1dm macrofabric. The segregation ice content within the upper parts of cryoturbated bedrock in modern periglacial environments may be as high as $70 \%$. The subsequent degradation of the permafrost leads to episodic melting of the segregated ice and rock settlement. Melting of ice-rich fragmented bedrock leads to 'collapse', mobilisation/displacement and formation of diamicton with a jumbled texture of increasingly randomly orientated blocks, i.e. comparable to the texture of the facies (iii) diamicton on Anglesey. The massive appearance of the facies (iii) diamicton would have been further promoted as a result of its subsequent reworking by the Irish Sea Ice.

\subsection{Periglacial soft-sediment deformation (post-glacial)}

The diamictons exposed on the northern-side of Porth Penrhyn-mawr at (SH 2843 8395) near to Penrhyn Farm (Fig 2) show evidence of having undergone deformation associated with periglacial activity. Here a well-developed preferred clast alignment within the bedrock-rich diamicton is deformed by a series of broad, open upright to steeply inclined synforms separated by narrow, tight antiforms (Fig. 3b). These convolute-style folds clearly deform the boundary between the bedrock-rich diamicton and overlying sandy Irish Sea diamicton. Several metres to the southeast of these involutions, pebble sized clasts within the sandy diamicton show a pronounced vertical alignment (Fig. 3c). Field evidence clearly indicates that this phase of periglacial activity on Anglesey post-dated the deposition of both the bedrock-rich and sandy diamictons, and probably occurred immediately after the Irish Sea Ice had retreated northwards, leaving the subglacial sediments and landforms of the western side of the island exposed to localised post-glacial modification.

Two principle mechanisms have been proposed for the formation of involutions within periglacial deposits: (i) 'periglacial involutions' formed by freeze-thaw processes (Sharp 1942; Washburn, 1980) and thereby indicating the former existence of permafrost 
and/or deep seasonal frost (French 1996 and references therein); and (ii) 'thermokarst involutions' with soft-sediment deformation occurring in response to either loading and buoyancy or by water-escape during the degradation of ice-rich permafrost (French 1979, 1996; Murton and French 1993). Murton and French (1993) demonstrated that thermokarst involutions are more common within finer grained sediments (silt, sand) and formed by fluidisation, necessitating the presence of water-saturated sediments prone to liquefaction or open-system groundwater conditions capable of generating artesian pressures. The overall pebble- to cobble grade of the involuted diamicton of western Anglesey is considered to be too coarse grained to promote the formation of involutions in response to loading and waterescape. Consequently, the convolute-style folding of this bedrock-rich diamicton is more likely to have formed in response to differential freezing and thawing, and the development and melting of masses of ground ice. The intensity of frost heave is controlled by the thermal gradient and position of the water table (Van Vliet-Lanoë, 1988). Frost heave caused by the development of ice segregations results in compression and incremental injection of the sediment either laterally or upwards. In modern permafrost environments, periglacial involutions are commonly associated with the development of patterned ground. Although periglacial involutions have been described from a number of other sites on Anglesey (e.g. Porth Cwyfan; Fig. 1b) (this study; Greenly, 1919; Stewart Campbell, personal communication 2010), no evidence of patterned ground has been reported from the island. On the north side of Penrhyn-mawr, although the involutions deform both the bedrock-rich diamicton and the base of the overlying Irish Sea diamicton, the convolute-style folds are most pervasively developed within the lower diamicton, suggesting that pressures developed in response to heave were primarily directed downward into the bedrock-rich diamicton. It is possible that the sandy Irish Sea diamicton may have been more frost-susceptible, forming a relatively rigid upper surface due to the frost, leading to the development of a negative frost susceptibility gradient (Van Vliet-Lanoë, 1988). As a result soft-sediment deformation would have been focused into the underlying diamicton. Furthermore, this would have potentially restricted the development of features associated with patterned ground on the surface (Van Vliet-Lanoë, 1988).

\section{Provenance of the diamictons on Anglesey}

The essentially bipartite sequence in western Anglesey comprises a lower diamicton dominated by very locally derived bedrock fragments overlain by the weakly to moderately stratified sandy Irish Sea diamicton which contains a high proportion of far-travelled detritus including Carboniferous and Devonian sedimentary rocks, erratic boulders of metabasalt and less common granitic rocks. Samples of the fine-grained matrix from both diamictons were collected from sites across the island (Table 1) for palynological analysis. The results of this study are summarised in Table 1.

The majority of the palynomorphs present within both diamictons are derived from the Carboniferous, with the bedrock-rich diamicton from across Anglesey also locally containing sparse palynofloras of Devonian, Mesozoic and Paleogene age (Table 1). Black wood fragments are common, with minor/rare Quaternary palynomorphs also present in some 
samples. The Carboniferous spores are overwhelmingly Densosporites spp. and Lycospora pusilla (Table 1). This assemblage also includes Tripartites vetustus, indicative of detritus derived from the Viséan/Serpukovian, as well as Cirratriradites saturni, Endosporites sp. and Radiizonates aligerens consistent with a Pennsylvanian provenance for the diamictons (Smith and Butterworth, 1967). Much of eastern Anglesey, North Wales and the adjacent offshore continental shelf is underlain by Carboniferous as well as Devonian and Mesozoic strata (Howells, 2007; Jackson et al., 1995), consistent with a largely local to Irish Sea source for at least part of the finer grained component to both diamictons. A Miocene palynoflora has also been recorded onshore on Anglesey preserved as a result of karstic subsidence of a large block of limestone within the Gwna Mélange exposed at Trwyn y Parc (SH 372 941) near Cemaes Bay (Walsh et al., 1996).

These data suggest that the sparse Devonian, Mesozoic and Paleogene palynofloras are absent in the sandy Irish Sea diamicton, even though this deposit apparently contains a greater proportion of far-travelled pebble to cobble sized clasts. The occurrence of 'fartravelled' palynomorphs within the very locally derived bedrock-rich diamicton of western Anglesey (e.g. sample 7, Cemlyn Bay and sample 10, Penrhos headland; see Table 1) is consistent with field evidence for the localised reworking and intermixing of more fartravelled detritus into this pre-existing periglacial deposit as the island was overridden by Irish Sea Ice. Consequently, the palynoflora extracted from both diamictons on Anglesey indicate a local to Irish Sea provenance for these deposits. Importantly no Lower Palaeozoic palynomorphs were identified in any of the samples, indicating that sediment supply from the adjacent Welsh Mainland was, at best, highly restricted.

\section{Implications for the glacial history of Anglesey}

The Late Devensian sedimentological and geomorphological record on Anglesey has largely been interpreted in terms of the processes occurring beneath the Irish Sea Ice Stream (Thomas and Chiverrell, 2007; Phillips et al., 2010). However, the results of this study, indicates that the island was subject to a period of periglacial activity prior to the arrival and overriding of Anglesey by this major ice stream. The bedrock-rich diamicton which crops out across Anglesey is interpreted as a variably reworked periglacial head deposit. This conclusion is supported by the very local derivation of the bedrock clasts within this superficial deposit and the occurrence of a locally developed inherited clast macrofabric (S1dm) which preserves the orientation of pre-existing tectonic structures in the underlying bedrock (e.g. S1 in the New Harbour Group). Initial fragmentation of the bedrock is considered to have occurred in response to the growth of ice along pre-existing structures, such as the S1 fabric in the New Harbour Group, within the bedrock (Büdel, 1982; French et al., 1986; Hallet et al., 1991; Murton, 1996; Murton et al., 2001, 2006). Solifluction and related mass movement processes may have resulted in the mobilisation and localised movement of the disaggregated bedrock to form the massive to weakly stratified facies (ii) and (iii) diamicton. The relatively low topography of the island would have limited the transport distances resulting in the observed close correlation between the composition of the bedrock-rich diamicton and the underlying bedrock geology. 
The interpretation of the bedrock-rich diamicton as a reworked head deposit, coupled with the proposed periglacial brecciation of the underlying bedrock, can be used to suggest that Anglesey remained relatively ice-free until it was overridden by the expanding Irish Sea Ice Stream. The interrelationships between the deformation structures present within the diamictons and underlying bedrock has allowed a relative chronology of events to be established. As this periglacial sequence was overridden by the Irish Sea Ice it was either bulldozed (reworked) by the advancing ice, and/or underwent glacitectonic deformation leading to thrusting, rafting of bedrock, hydrofracturing and fabric development within both the diamicton and underlying bedrock (see Fig. 2). Harris (1991) recorded open and sandfilled joints (hydrofractures) within the bedrock cores from boreholes in the Wylfa Head area to a depth of at least $5 \mathrm{~m}$ and possibly up to $20 \mathrm{~m}$, indicating that either the permafrost and/or subsequent glacitectonism locally penetrated to a depth of several metres into bedrock. The recognition of hydrofractures cutting the bedrock may potentially be used as a key indicator for the development of an overpressurised subglacial hydrogeological system beneath the Irish Sea Ice Stream.

The preservation of areas of periglacially deformed/fragmented bedrock beneath the Irish Sea diamicton suggests that the permafrost may have been still been partially frozen as it was overridden by the Irish Sea Ice. These areas of relict permafrost were frozen to the bedrock and so relatively resistant to reworking by the advancing ice. In the study area there is a progressive increase in the intensity of glacitectonism of both the bedrock and bedrockrich diamicton towards the northwest, i.e. in an up-ice direction (Fig. 2). Consequently, rather than simply being bulldozed by the advancing Irish Sea Ice, the up-ice side of these areas of relict permafrost appear to have been the focus of locally intense ice marginal to subglacial deformation leading to thrusting, brittle shearing and foliation development (Figs. 2 and 9 to 11). Kinematic indicators (thrusts, asymmetrical folds, brittle shear fabric) all record a southerly sense of shear, which is consistent with the overall southwest direction of ice movement across Anglesey recorded by subglacial landforms. Further evidence for the permafrost having potentially remained frozen as it was overridden by the Irish Sea ice is provided by the rafts of New Harbour Group. Internally these rafts are locally highly fractured (Fig. 9), largely as a result of the opening of pre-existing joints and S1 fabric, with fracturing having occurred prior to rafting (possibly periglacial in origin). Although fractured, the bedrock raft remained intact during its detachment and subsequent transport by the ice suggesting that the New Harbour Group schists may have been frozen during the rafting process. The thrusts and other glacitectonic deformation structures in the lower bedrock-rich diamicton are clearly truncated at the base of the Irish Sea diamicton, indicating that glacitectonism occurred at an early stage during the advance of the Irish Sea Ice and predated the deposition of this sandy diamicton.

As noted above, the interpretation of the bedrock-rich diamicton as a reworked, preglacial head deposit suggests that Anglesey remained ice free until it was overridden by the Irish Sea Ice Stream. Greenly (1919) identified a tripartite succession at Lleiniog (SH 619 787; Fig. 1b), northeast of Beaumaris on the western side of the Menai Strait. This succession consists of a lower 'blue till' which Greenly (1919) considered to be a product of 'Welsh ice' 
impinging onto Anglesey in the Menai Strait area. This till is overlain by glacial outwash sands and gravels (Whittow and Ball, 1970; Helm and Roberts, 1984; Campbell and Bowen, 1989), which are in-turn overlain by an upper sandy diamicton containing large Carboniferous limestone erratics, interpreted as having deposited by Irish Sea Ice (Greenly, 1919). Glaciers flowing west to northwest from the Snowdonia ice cap would have been captured/diverted by a palaeovalley marked the present-day Menai Straits. Consequently, it is unlikely that ice emanating from North Wales did not extend far onto Anglesey (Greenly, 1919). This is supported by the palynological data presented here which clearly demonstrates that the diamictons on Anglesey have an Irish Sea provenance. Importantly, no Lower Palaeozoic palynomorphs were identified within any of the samples of 'blue till', and consequently, an origin from the Welsh mainland for this earlier 'till' is not supported. Instead, it is considered that Anglesey remained ice-free until it was overridden by ice flowing down the Irish Sea Basin allowing the development of an ?extensive permafrost layer across this low-lying island. The involutions/convolute folds which locally deformed both the lower bedrock-rich diamicton and overlying Irish Sea diamicton (e.g. at Porth Penrhyn-mawr, Porth Cwyfan) clearly post-date this advance indicating that periglacial conditions were reestablished on Anglesey after the retreat of the Irish Sea Ice.

\section{Conclusions}

The glacigenic succession exposed in the coastal cliffs of western Anglesey in northwest Wales record the development of a permafrost layer prior to the island having been overridden by the Devensian (Weichselian) Irish Sea Ice Stream. The metasedimentary bedrock and overlying bedrock-rich diamicton preserve clear evidence of having undergone both periglacial and glacitectonic deformation. The interrelationships between these deformation structures have allowed a relative chronology of events to be established, which indicate that the Irish Sea Ice overrode, interacted with, and variably reworked the preexisting permafrost layer. These findings have important implications for the glacial history of Anglesey, indicating that the island remained relatively ice-free prior to its inundation by ice flowing southwards down the Irish Sea Basin. Permafrost was subsequently re-established on Anglesey after the Irish Sea Ice Stream had retreated resulting in the formation of involutions which deform both the lower bedrock-rich and overlying Irish Sea diamictons. Palynological data obtained from the diamictons across Anglesey clearly demonstrates that they have an Irish Sea provenance. Crucially, no Lower Palaeozoic palynomorphs were identified in any of the samples, indicating that it is unlikely that the island was overridden by ice emanating from the Snowdon ice cap on the adjacent Welsh mainland.

Similar structures to those identified within the superficial deposits of Anglesey are likely to have developed in other regions of glaciated terrane were frost-susceptible bedrock has undergone brecciation in response to permafrost activity prior to being overridden by glacier ice. 


\section{Acknowledgements}

This work forms part of the British Geological Survey's Geology and Landscape Wales Programme. Dave Schofield, Adrian Humpage, Geoff Thomas, Julian Murton, Richard Waller, Amanda Williams and Helen Burke are acknowledged for helpful discussions and comments on an earlier version of this manuscript. Jasper Knight and, in particular, the second anonymous referee are thanked for their constructive and positive reviews of this paper. This paper is published with the permission of the Executive Director, British Geological Survey (National Environmental Research Council).

\section{References}

Astakhov, V.I., Kaplyanskaya, F.A., Tarnogradskiy, V.D., 1996. Pleistocene permafrost of West Siberia as a deformable glacier bed. Permafrost and Periglacial Processes 7, 165-191.

Ballantyne, CK., Harris, C., 1994. The periglaciation of Great Britain. Cambridge University Press, Cambridge, pp 330.

Bates, D.E.B., 1972. The stratigraphy of the Ordovician rocks of Anglesey. Geological Journal 8, 29-58.

Beckly, A.J., 1987. Basin development in North Wales during the Arenig. Geological Journal 22, 19-30.

Bennett, M.R., 2003. Ice streams as the arteries of an ice sheet: their mechanics, stability and significance. Earth Science Reviews 61, 309-339.

Büdel, J., 1982. Climatic Geomorphology. Princeton University Press, Princeton.

Campbell, S., Bowen, D.Q. 1989. Quaternary of Wales. Geological Conservation Review Volume. Joint Nature Conservation Committee. Peterborough.

Clark, C.D., Hughes, A.L.C., Greenwood, S.L., Jordan, C., Sejrup, H.P. 2012. Pattern and retreat of the last British-Irish Ice Sheet. Quaternary Science Reviews, in press.

Collins, A., Buchan, C., 2004. Provenance and age constraints of the South Stack Group, Anglesey, UK: U-Pb SIMS detrital zircon data. Journal of the Geological Society of London $161,743-746$.

Cuffey, K.M., Conway, H., Hallet, B., Gades, A.M., Raymond, C.F. 1999. Interfacial water in polar glaciers and glacier sliding at $-17^{\circ} \mathrm{C}$. Geophysical Research Letters $26,751-754$.

Cutler, P.M., MacAyeal, D.R., Mickelson, D.M., Parizek, B.R., Colgan, P.M., 2000. A numerical investigation of ice-lobe-permafrost interaction around the southern Laurentide ice sheet. Journal of Glaciology 46, 311-325.

Echelmeyer, K., Zhongxiang, W., 1987. Direct observations of basal sliding and deformation of basal drift at subfreezing temperatures. Journal of Glaciology. 33, 83-98. 
Evans, D.J.A., Ó Cofaigh, C., 2003. Depositional evidence for marginal oscillations of the Irish Sea ice stream in southeast Ireland during the last glaciation. Boreas 32, 76-101.

Eyles, N., McCabe, A.M., 1989. The Late Devensian (<22,000 BP) Irish Sea Basin: the sedimentary record of a collapsed ice sheet margin. Quaternary Science Reviews 8, 307-351.

Fitzsimons, S.J., McManus, K.J., Lorrain, R.D., 1999. Structure and strength of basal ice and substrate of a dry-based glacier: evidence for substrate deformation at sub-freezing temperatures. Annals of Glaciology 28, 236-240.

French, H.M., 1979. Periglacial geomorphology. Progress in Physical Geography 3, 264-273.

French, H.M., 1996. The Periglacial Environment, $2^{\text {nd }}$ Edition. Longman, Harrow.

French, H.M., Bennett, L., Hayley, D.W., 1986. Ground ice conditions near Rea Point and on Sabine Peninsula, eastern Melville Island. Canadian Journal of Earth Sciences 23, 1389-1400.

Greenly, E., 1919. The geology of Anglesey. Memoir (District) Geological Survey of Great Britain. HMSO, London 980.

Haeberli, W., 2005. Investigating glacier-permafrost relationships in high-mountain areas: historical background, selected examples and research needs. In Harris, C., Murton, J.B. (Eds.), Cryospheric Systems: Glaciers and Permafrost. Geological Society of London, Special Publications, 242, 29-37.

Hambrey, M.J., Davies, J.R., Glasser, N.F., Waters, R.A., Dowdeswell, J.A., Wilby, P., Wilson, D., Etienne, J.L., 2001. Devensian glacigenic sedimentation and landscape evolution in the Cardigan area of southwest Wales. Journal of Quaternary Science 16, 455-479.

Hall, K., 1999. The role of thermal stress fatigue in the breakdown of rock in cold regions. Geomorphology 31, 47-63.

Hall, K., Thorn, C. E., Matsuoka, N., Prick, A., 2002. Weathering in cold regions: some thoughts and perspectives. Progress in Physical Geography 26, 577-603.

Hallet, B., Walder, J.S., Stubbs, C.W. 1991. Weathering by segregation ice growth in microcracks at sustained subzero temperatures: verification from an experimental study using acoustic emissions. Permafrost and Periglacial Processes 2, 283-300.

Harris, C. 1991. Glacial deposits at Wylfa Head, Anglesey, North Wales: evidence for Late Devensian deposition in a non-marine environment. Journal of Quaternary Science 6, 67-77.

Harris, C. 1998. The micromorphology of paraglacial and periglacial slope deposits: a case study from Morfa Bychan, west Wales, UK. Journal of Quaternary Science 13, 73-84.

Harris, C., Williams, G., Brabham, P. Eaton, G., McCarroll, D., 1997. Glacitectonized Quaternary sediments at Dinas Dinlle, Arvon, North Wales and their bearing on the style of deglaciation in the eastern Irish Sea. Quaternary Science Reviews 16, 109-127. 
Harris, C., Murton, J.B., 2005. Interactions between glaciers and permafrost: an introduction. In Harris, C., Murton, J.B. (Eds.), Cryospheric Systems: Glaciers and Permafrost. Geological Society of London, Special Publications 242, 1-9.

Helm, D.G., Roberts, B., 1984. The origin of late Devensian sands and gravels, southeast Anglesey, N. Wales. Geological Journal 19, 33-55.

Hiemstra, J.F., Evans, D.J.A., Scourse, J.D., Furze, M.F.A., D. McCarroll, E. Rhodes. 2006. New evidence for a grounded Irish Sea glaciation of the Isles of Scilly, U.K. Quaternary Science Reviews 25, 299-309.

Higginbottom, I.E., Fookes, P.G., 1970. Engineering aspects of periglacial features in Britain. Quarterly Journal of the Geological Society 108, 233-256.

Howells, M.F., 2007. British Regional Geology: Wales. British Geological Survey.

Jackson, D.I., Jackson, A.A., Evans, D., Wingfield, R.T.R., Barnes, R.P., Arthur, M.J., 1995. The geology of the Irish Sea. United Kingdom Offshore Regional Report 20-24. HMSO for the British Geological Survey, London.

Jansson, K.N., Glasser, N.F., 2005. Palaeoglaciology of the Welsh sector of the British-Irish Ice Sheet. Journal of the Geological Society of London 162, 25-37.

Maltman, A.J., 1977. The Serpentinites and related rocks of Anglesey. Geological Journal 12, 113-128.

Mathews, W.H., Mackay, J.R., 1960. Deformation of soils by glacier ice and the influence of pore pressures and permafrost. Transactions of the Royal Society of Canada 54, 27-36.

McCarroll, D., 2001. Deglaciation of the Irish Sea Basin: a critique of the glacimarine model. Journal of Quaternary Science 16, 393-404.

Merritt, J.W., Auton, C.A., 2000. An outline of the lithostratigraphy and depositional history of Quaternary deposits in the Sellafield district, west Cumbria. Proceedings of the Yorkshire Geological Society 53, 129-154.

Murton, J.B. 1996. Near-surface brecciation of chalk, Isle of Thanet, south-east England: a comparison with ice-rich brecciated bedrocks in Canada and Spitsbergen. Permafrost and Periglacial Processes 7, 153-164.

Murton, J.B., French, H.M. 1993. Thermokarst involutions, Summer Island, Pleistocene Mackenzie Delta, Western Canadian Arctic. Permafrost and Periglacial Processes 4, 217-229.

Murton, J.B., Coutard, J-P., Lautridou, J-P., Ozouf, J-C., Robinson, D.A., Williams, R.G.B., Guillemet, G., Simmons, P. 2000. Experimental design for a pilot study on bedrock weathering near the permafrost table. Earth Surface Processes and Landforms 25, 1281-1294.

Murton, J.B., Peterson, R., Ozouf, J-C., 2006. Bedrock fractured by ice segregation in cold regions. Science 314, 1127-1129. 
Ó Cofaigh, C., Evans, D.J.A., 2001. Sedimentary evidence for deforming bed conditions associated with a grounded Irish Sea glacier, Southern Ireland. Journal of Quaternary Science $16,435-454$.

Patterson, C.J., 1998. Laurentide glacial landscapes: the role of ice streams. Geology 26, 643-646.

Passchier, C.W. \& Trouw, R.A.J. 1996: Microtectonics, 289 pp. Springer-Verlag, Berlin, Heidelberg.

Phillips, E.R., 1989. The Geology of the Monian Supergroup, Western Anglesey, North Wales. Unpublished PhD thesis, University of Wales, Cardiff, pp 470.

Phillips, E.R., 1991a. The lithostratigraphy, sedimentology and tectonic setting of the Monian Supergroup, western Anglesey, North Wales. Journal of the Geological Society of London 148, 1079-1090.

Phillips, E.R., 1991b. Progressive deformation of the South Stack and New Harbour Groups, Holy Island, western Anglesey, North Wales. Journal of the Geological Society of London 148, 1091-1100.

Phillips, E.R., Auton, C.A., 2008. Microtextual analysis of a glacially 'deformed' bedrock: implications for inheritance of preferred clast orientations in diamictons. Journal of Quaternary Science. 23, 229-240.

Phillips, E.R., Everest, J., Diaz-Doce, D., 2010. Bedrock controls on subglacial landform distribution and geomorphological processes: Evidence from the Late Devensian Irish Sea Ice Stream. Sedimentary Geology 232, 98-118.

Phillips, E.R., Lee, J.R., Evans, H.M. (eds.) 2011. Glacitectonics - Field Guide. Quaternary Research Association.

Riding, J.B., Kyffin-Hughes, J.E. 2004. A review of the laboratory preparation of palynomorphs with a description of an effective non-acid technique. Revista Brasileira de Paleontologia, No. 7(1), 13-44.

Riding, J.B., Kyffin-Hughes, J.E. 2006. Further testing of a non-acid palynological preparation procedure. Palynology, 30, 69-87.

Roberts, D.H., Dackombe, R.V., Thomas, G.S.P., 2007. Palaeo-ice streaming in the central sector of the British-Irish Ice Sheet during the Last Glacial Maximum: evidence from the northern Irish Sea Basin. Boreas 36,115-129.

Scourse, J.D., 1991a. Late Pleistocene stratigraphy and palaeobotany of the Isles of Scilly. Philosophical Transactions of the Royal Society of London B334, 405-448.

Scourse, J.D., 1991b. Glacial deposits of the Isles of Scilly. In Ehlers, J., Gibbard, P.L., Rose, J., (eds.) Glacial Deposits in Great Britain and Ireland. A.A. Balkema, Rotterdam 291-300. 
Scourse, J.D., Furze, M.F.A., 2001. A critical review of the glaciomarine model for Irish Sea deglaciation: evidence from southern Britain, the Celtic shelf and adjacent continental slope. Journal of Quaternary Science 16, 419-434.

Shackleton, R.M., 1969. The Precambrian of North Wales. In Wood, A., (ed.) The Precambrian and Lower Palaeozoic rocks of Wales. University of Wales Press, Cardiff 1-22.

Shackleton, R.M., 1975. Precambrian rocks of Wales. In Harris, A.L., et al., (eds.) A correlation of the Precambrian rocks in the British Isles. Geological Society of London, Special Report 6, 76-82.

Smith, A.H.V., Butterworth, M.A., 1967. Miospores in the coal seams of the Carboniferous of Great Britain. Special Papers in Palaeontology No. 1, 324 p.

Sharp, R.P., 1942. Periglacial involutions in Illinois. Journal of Geology 50, 113-133.

Thomas, G.S.P., Chiverrell, R.C., Huddart, D., 2004. Ice-marginal depositional responses to probable Heinrich events in the Devensian deglaciation of the Isle of Man. Quaternary Science Reviews 23, 85-106.

Thomas, G.S.P., Chiverrell, R.C., 2007. Structural and depositional evidence for repeated icemarginal oscillation along the eastern margin of the Late Devensian Irish Sea Ice Stream. Quaternary Science Reviews 26, 2375-2405.

Van Landeghem, K.J.J., Wheeler, A.J., Mitchell, N.C., 2009. Seafloor evidence for palaeoice streaming and calving of the grounded Irish Sea Ice Stream: Implications for the interpretation of its final deglaciation phase. Boreas 38, 119-131.

Van Vliet-Lanoë, B., 1988. The significance of cryoturbation phenomena in environmental reconstruction. Journal of Quaternary Science 3, 85-96.

Waller, R.I., 2001. The influence of basal processes on the dynamic behaviour of cold based glaciers. Quaternary International 86, 117-128.

Waller, R.I., Murton, J.B., Kristensen, L., 2012. Glacier-permafrost interactions: Processes, products and glaciological implications. Sedimentary Geology 255-256, 1-28.

Walsh, P., Morawiecka, I., Skawińska-Wieser, K. 1996. A Miocene palynoflora preserved by karstic subsidence in Anglesey and the origin of the Menaian Surface. Geological Magazine. 133, 713-719.

Washburn, A.L., 1980. Geocryology. Wiley, New York, pp 406.

Whittow, J.B., Ball, D.F., 1970. North-west Wales. In Lewis, C.A. (ed.) The Glaciations of Wales and Adjoining Areas. Longman, London, pp 21-58. 


\section{Figure captions}

Fig. 1. (a) Map of the British Isles showing the location of Anglesey; (b) map of Anglesey showing the three sediment-landform assemblage zones identified by Thomas and Chiverrell (1979) and Phillips et al. (2010), and the location of the study area; and (c) Simplified bedrock geological map of the Porth Penrhyn-mawr to Porth Tywyn-mawr area (from Phillips, 1989). Also shown are the location of the key sections through the overlying superficial deposits.

Fig. 2. Schematic cross-section through the section exposed between the northern side of Porth Penrhyn-mawr and Porth Delysg.

Fig. 3. (a) Glacial succession (maximum thickness 10-15 m) exposed at Porth Dryw (SH 282 840) comprising a lower massive to weakly stratified, green-grey bedrock-rich diamicton overlain by a stratified brown, sandy diamicton correlated with the Irish Sea Till facies; (b) Convolute-style folding of a well-developed clast macrofabric resulting from the periglacial deformation of the bedrock-rich diamicton exposed on the north side of Porth Penrhyn-mawr (SH 2843 8395); and (c) Vertically aligned clasts within the sandy Irish Sea diamicton exposed on the north side of Porth Penrhyn-mawr (SH 2843 8395).

Fig. 4. Lower hemisphere stereographic projections showing the structural and clast orientation data obtained from the New Harbour Group metasedimentary rocks and overlying bedrock-rich diamicton: (a) dip and dip-direction of S1 in the New Harbour Group (point data and contour plot); (b) dip and dip-direction of joints (fractures) in the New Harbour Group and a bedrock raft (point data and contour plot); (c) contour plot of plunge and trend of F2 folds in western Anglesey (Phillips, 1989; 1991b) and point data of F2 folds in the bedrock exposed between Porth Penrhyn-mawr to Porth Tywyn-mawr as well as folds preserved within the bedrock raft; and (d) orientation of schistosity in bedrock clasts (S1dm) within the diamicton (point data and contour plot) (see text for details).

Fig. 5. (a) Overview of southern end of deformed bedrock section exposed on the southern side of Porth Delysg (SH 2808 8410) showing clast-supported, bedrock-rich diamicton overlain by sandy Irish Sea diamicton; (b) Details of area of fragmented bedrock within the diamicton with well-developed preferred shape alignment of tabular to slab-like clasts of chlorite-quartz-schist preserving the original orientation of both the S1 and S3 tectonic fabrics within the New Harbour Group (see text for details); (c) Clast- to matrix-supported, massive diamicton composed almost entirely of randomly orientated clasts of New Harbour Group chlorite-quartz-schist; and (d) to (g) Lower hemisphere stereographic projections of dip and dip direction of S1 within the New Harbour Group (d), clasts orientation within the massive diamicton (e), dip and dip direction of S1dm schistosity in clasts in area of fragmented bedrock (f) and dip and dip direction of S3 within the aligned bedrock clasts (g).

Fig. 6. (a) and (b) Detailed photographs of area of fragmented New Harbour Group bedrock showing the well-developed preferred shape alignment of tabular to slab-like fragments of chlorite-quartz-schist. The shape of the clasts is controlled by the pervasively developed S1 
schistosity. Fragmentation of the bedrock occurred due to the opening of fractures along the pre-existing S1 and S3 fabrics (see text for details).

Fig. 7. (a) Bedrock-rich diamicton composed of angular, randomly orientated clasts of New Harbour Group chlorite-quartz-schist. Overall decrease in the size of the bedrock fragments results in a crude normal grading within this essentially massive diamicton; and (b) Stratified or layered bedrock-rich diamicton in which a well-developed clast macrofabric within the upper part of the diamicton is deformed by an open antiform-synform pair with southerly dipping axial surfaces.

Fig. 8. (a) and (b) Sub-horizontal to gently northerly dipping stratification within the bedrock-rich diamicton; and (c) Lower hemisphere stereographic projections of dip and dip direction of S1 within the New Harbour Group and bedrock clasts within the overlying diamicton.

Fig. 9. (a) and (b) Lenticular raft of New Harbour Group enclosed within the bedrock-rich diamicton. The S1 fabric preserved within the raft is folded by a southeast-verging, mesoscale F2 fold.

Fig. 10. (a) and (b) Network of hydrofractures cutting the New Harbour Group and filled by highly fragmented, fine grained (up to $2 \mathrm{~cm}$ ) chlorite-quartz-schist and vein quartz within a chloritic matrix. The fill to the hydrofractures is lithologically similar to the matrix of the overlying bedrock-rich diamicton; and (c) and (d) Glacitectonised bedrock-rich diamicton with a variably developed planar to asymmetrical, brittle foliation defined by shape-aligned fragments of chlorite-quartz-schist (see text for details).

Fig. 11. (a) and (b) Highly sheared and deformed New Harbour Group and bedrock-rich diamicton exposed at the northern end of the section (SH 2818 8430). This foliated glacitectonite is deformed a complex set of reverse and normal brittle faults (see text for details). 


\section{Tables}

Table 1. A summary of the provenance of the diamictons on Anglesey based upon their palynology. $\mathrm{Ab}=\mathrm{abundant} ; \mathrm{P}=\mathrm{present} ; \mathrm{R}=\mathrm{rare} ; \ldots=$ absent.

\begin{tabular}{|c|c|c|c|c|c|c|c|c|c|}
\hline \multirow{2}{*}{$\begin{array}{l}\text { Sample } \\
\text { number }\end{array}$} & \multirow[t]{2}{*}{ Location } & \multirow[t]{2}{*}{ Grid Reference } & \multirow[t]{2}{*}{ Lithology } & \multirow[t]{2}{*}{ Palynomorph Assemblage } & \multicolumn{5}{|c|}{ Relative abundance } \\
\hline & & & & & 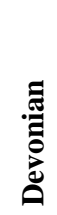 & 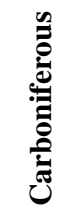 & 若 & 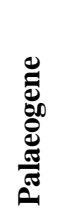 & 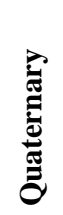 \\
\hline 1 & Sea Zoo & SH 247048364257 & $\begin{array}{l}\text { red diamicton } \\
\text { (Irish Sea } \\
\text { Diamicton) }\end{array}$ & $\begin{array}{l}\text { Carboniferous - Densosporites spp., Lycospora pusilla; } \\
\text { Cirratriradites saturni, ?Convolutispora sp., Endosporites sp., } \\
\text { Radiizonates aligerens, ?Raistrickia sp., Simozonotriletes intortus, } \\
\text { Tripartites vetustus, Tripartites sp., Tripartites vetustus, } \\
\text { Cirratriradites saturni, Endosporites sp., Radiizonates aligerens. } \\
\text { Quaternary - undifferentiated dinoflagellate cysts }\end{array}$ & $\cdots$ & $\mathrm{Ab}$ & $\ldots$ & $\ldots$ & $\mathrm{R}$ \\
\hline 2 & Beaumaris & SH 261309377694 & $\begin{array}{l}\text { grey diamicton } \\
\text { (head deposit) }\end{array}$ & $\begin{array}{l}\text { Devonian - Hystricosporites sp. } \\
\text { Carboniferous - Densosporites spp., Lycospora pusilla, } \\
\text { Calamospora spp., Simozonotriletes intortus } \\
\text { Mesozoic - Classopollis } \\
\text { Quaternary - undifferentiated dinoflagellate cysts, Spiniferites } \\
\text { spp., Alnus }\end{array}$ & $\mathrm{R}$ & $\mathrm{Ab}$ & $\mathrm{R}$ & $\cdots$ & $\mathrm{P} / \mathrm{R}$ \\
\hline 3 & Sea Zoo & SH 247077364258 & red mudstone & Quaternary - undifferentiated dinoflagellate cysts & $\ldots$ & $\ldots$ & $\ldots$ & $\ldots$ & $\mathrm{P}$ \\
\hline 4 & $\begin{array}{l}\text { Cemlyn } \\
\text { Bay }\end{array}$ & SH 232830393741 & $\begin{array}{l}\text { sand from } \\
\text { hydrofracture }\end{array}$ & Carboniferous - Densosporites, ?Simozonotriletes intortus & $\cdots$ & $\mathrm{R}$ & $\cdots$ & $\ldots$ & $\cdots$ \\
\hline 5 & Beaumaris & SH 261350377722 & $\begin{array}{l}\text { red diamicton } \\
\text { (Irish Sea } \\
\text { Diamicton) }\end{array}$ & $\begin{array}{l}\text { Carboniferous - Densosporites spp., Lycospora pusilla, } \\
\text { Calamospora spp., ?Simozonotriletes intortus }\end{array}$ & $\cdots$ & $\mathrm{P}$ & $\cdots$ & $\cdots$ & $\cdots$ \\
\hline 6 & $\begin{array}{l}\text { Cemlyn } \\
\text { Bay }\end{array}$ & SH 232743393750 & $\begin{array}{l}\text { red diamicton } \\
\text { (Irish Sea } \\
\text { Diamicton) }\end{array}$ & $\begin{array}{l}\text { Carboniferous -?Densosporites spp., Lycospora pusilla } \\
\text { Quaternary - undifferentiated pollen grains }\end{array}$ & $\ldots$ & $\mathrm{R}$ & $\ldots$ & $\ldots$ & $\mathrm{P}$ \\
\hline
\end{tabular}




\begin{tabular}{|c|c|c|c|c|c|c|c|c|c|}
\hline 7 & $\begin{array}{l}\text { Cemlyn } \\
\text { Bay }\end{array}$ & SH 232815393750 & $\begin{array}{l}\text { grey diamicton } \\
\text { (head deposit) }\end{array}$ & $\begin{array}{l}\text { Carboniferous - Densosporites spp., Lycospora pusilla } \\
\text { Mesozoic - Classopollis }\end{array}$ & $\ldots$ & $\mathrm{R} / \mathrm{P}$ & $\mathrm{R}$ & $\ldots$ & $\ldots$ \\
\hline 8 & Hen Borth & SH 232065392984 & $\begin{array}{l}\text { red diamicton } \\
\text { (Irish Sea } \\
\text { Diamicton) }\end{array}$ & Carboniferous - Densosporites spp., Lycospora pusilla & $\ldots$ & $\mathrm{R}$ & $\ldots$ & $\ldots$ & $\ldots$ \\
\hline 9 & Hen Borth & SH 232065392984 & $\begin{array}{l}\text { grey diamicton } \\
\text { (head deposit) }\end{array}$ & Carboniferous - ?Densosporites spp., Lycospora pusilla & $\ldots$ & $\mathrm{R}$ & $\ldots$ & $\cdots$ & $\ldots$ \\
\hline 10 & Penrhos & SH 227734381424 & $\begin{array}{l}\text { grey diamicton } \\
\text { (head deposit) }\end{array}$ & $\begin{array}{l}\text { Carboniferous - Densosporites spp., Lycospora pusilla } \\
\text { Cretaceous -Cribroperidinium sp. } \\
\text { Mesozoic - Classopollis. } \\
\text { Paleogene - Wetzeliella. } \\
\text { Quaternary - Alnus, Taraxacum, Tilia, Pediastrum. }\end{array}$ & $\ldots$ & $\mathrm{Ab}$ & $\mathrm{P} / \mathrm{R}$ & $\mathrm{R}$ & $\mathrm{P}$ \\
\hline 11 & $\begin{array}{l}\text { Porth } \\
\text { Nobla }\end{array}$ & SH 233050371119 & $\begin{array}{l}\text { red diamicton } \\
\text { (Irish Sea } \\
\text { Diamicton) }\end{array}$ & Quaternary - undifferentiated pollen grains & $\cdots$ & $\cdots$ & $\cdots$ & $\ldots$ & $\mathrm{R}$ \\
\hline
\end{tabular}




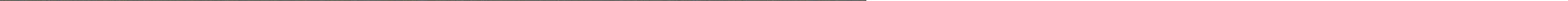




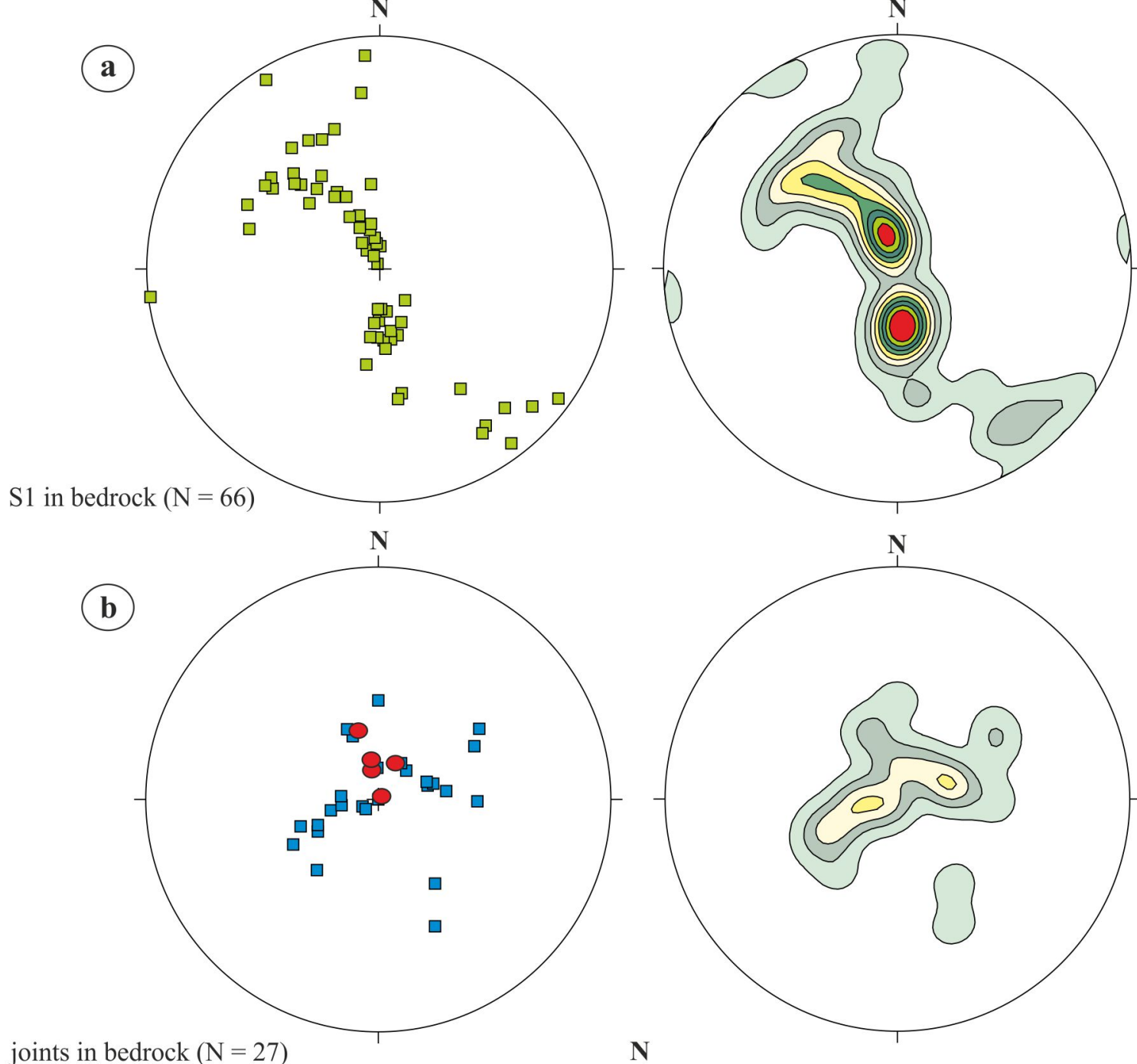

joints in bedrock $(\mathrm{N}=27)$ joints in raft $(\mathrm{N}=5)$

$\mathrm{F} 2$ folds $(\mathrm{N}=12)$ in bedrock and $\mathrm{F} 2$ folds in bedrock raft $(\mathrm{N}=2)$
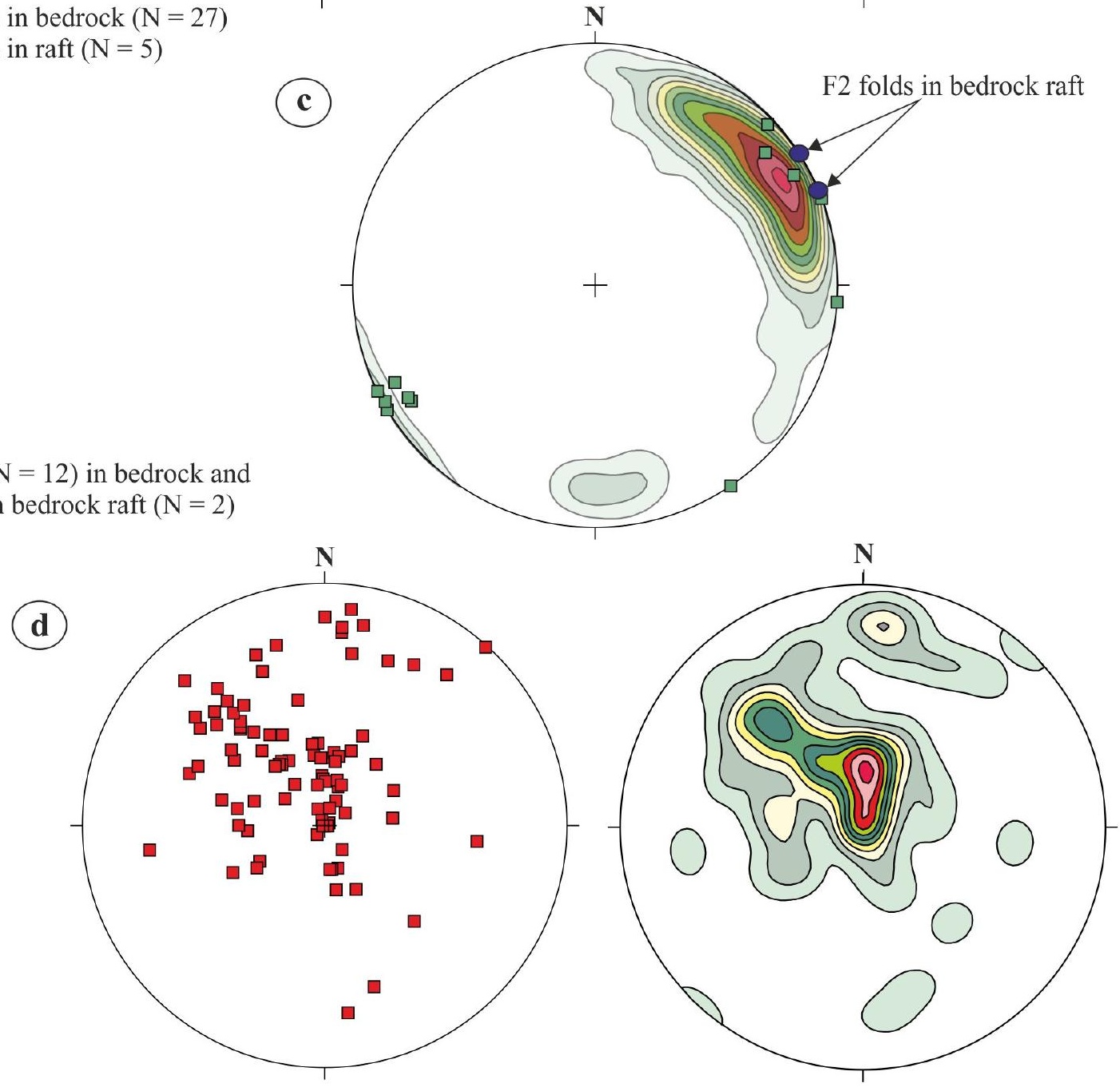

clast orientation $(\mathrm{S} 1 \mathrm{dm})$ in diamicton $(\mathrm{N}=87)$ 


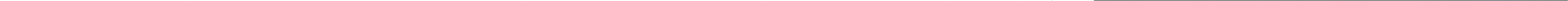




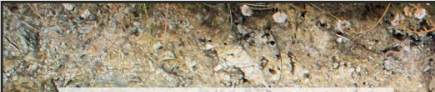

bedrock-rich diamicton

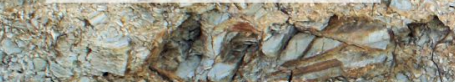

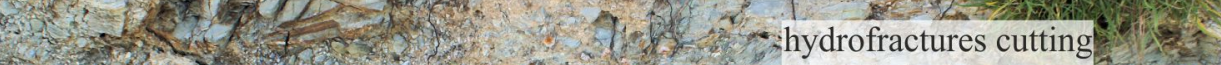

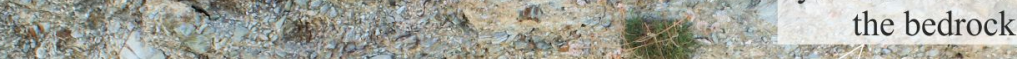

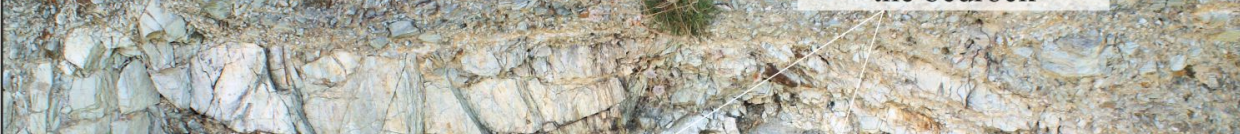

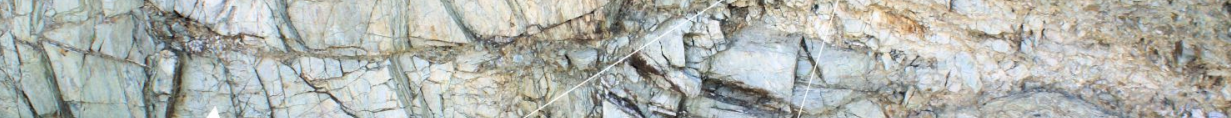

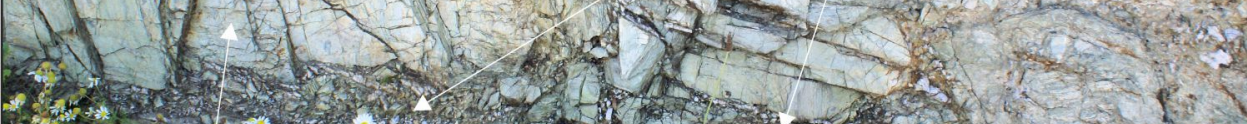

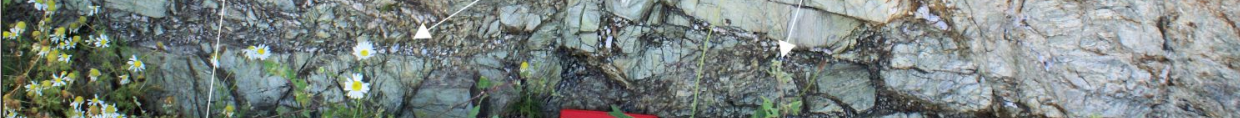

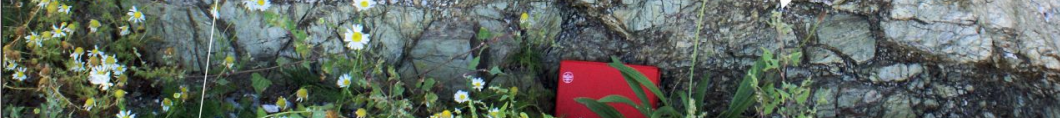
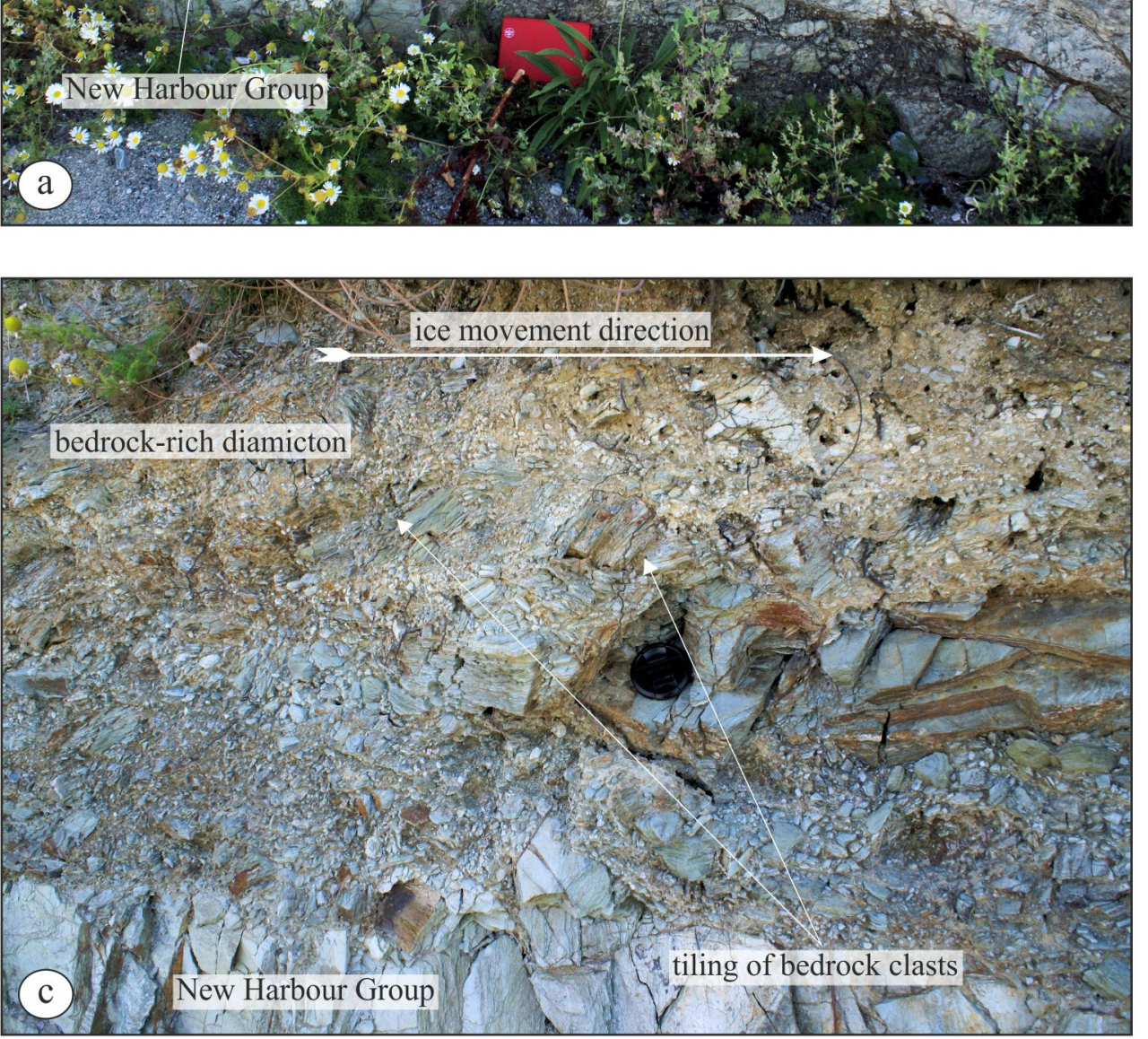
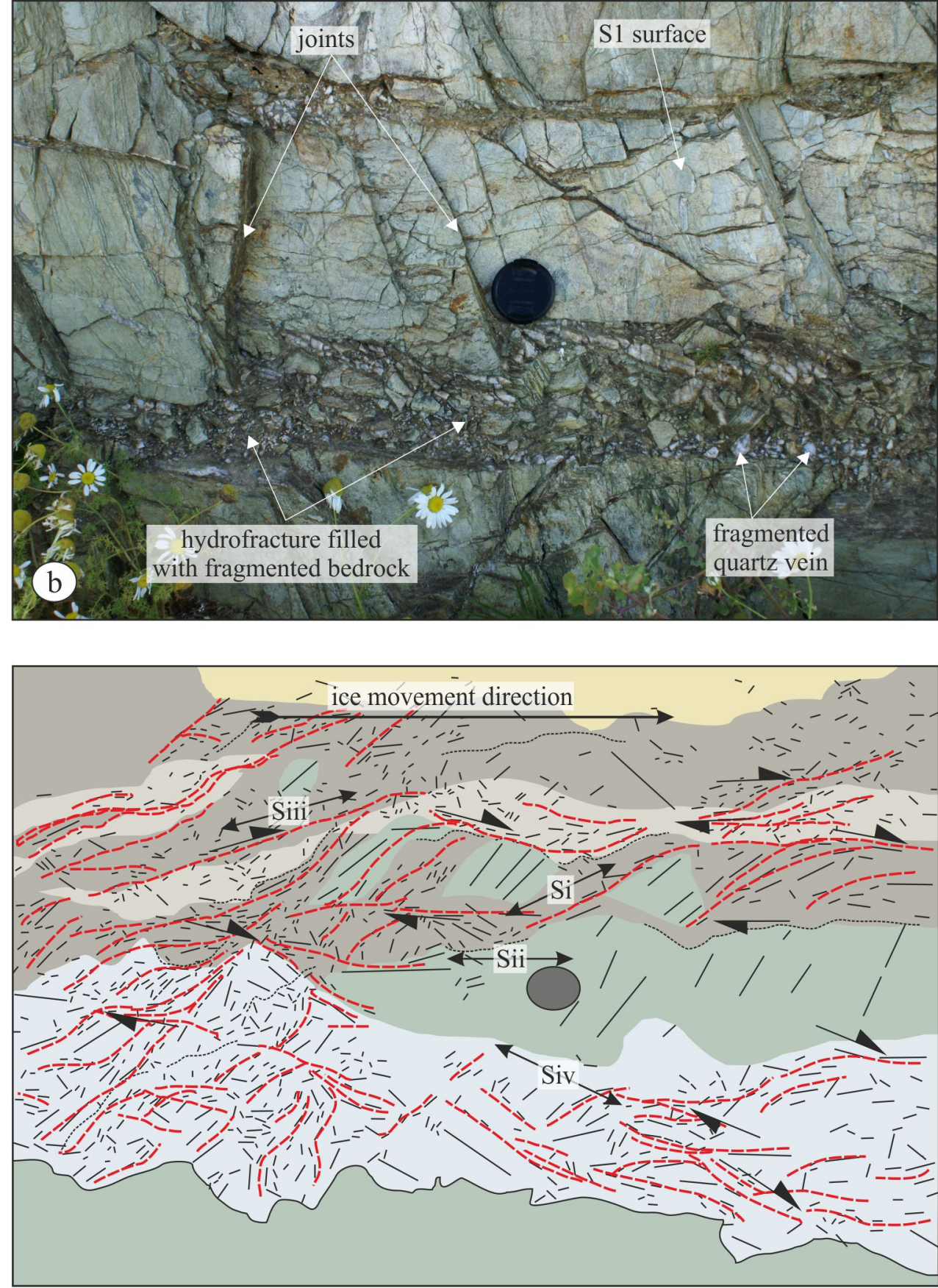

-.- dominant clast alignment fabrics

clast long axis

boundaries

$\Longrightarrow$ sense of shear 
